\title{
Metazoan Parasites of the European Sea Bass Dicentrarchus labrax (Linnaeus 1758) (Pisces: Teleostei) from Corsica
}

\author{
Laetitia Antonelli and Bernard Marchand \\ Laboratory "Parasites et Ecosystèmes Méditerranéens", \\ University Pasquale Paoli, Corsica
}

France

\section{Introduction}

As in many parts of the world, aquaculture production in the Mediterranean has been expanding rapidly over recent years (Basurco \& Lovatelli, 2005). The continuous decline of ocean fisheries stocks has provided impetus for rapid growth in aquaculture. Global production of farm fish has more than doubled in the past 20 years with the growing demands of an expanding population, and it seems that grow is set to continue. It has been the fastest growing food production sector since 1970, with an increase at a compounded rate about 9.2\% per year (Guo \& Woo, 2009; Naylor et al., 2000). Alongside, and perhaps partly due to this rapid expansion, the welfare of farmed fish has received increasing attention. Fish welfare is an important issue for the industry, not just for public perception, marketing and product acceptance, but also often in terms of production efficiency, quality and quantity (Ashley, 2006). Many factors influenced the rapid increase in the production of cultured fish species in the last two decades (FAO, 2010). One of the most important factors is the great development and diffusion of sea-cage culture. The success of the sea-cage farming is essentially correlated with the possibility to reduce production cost. On the other hand, aquaculture of fish is not without problems. Cages constitute an open system, which allow free exchange between wild and caged organisms, leading to the emergence of characteristic diseases (Ghittino et al., 2003; Merella et al., 2006). The maintenance of a good health is a major problem in animal populations. Rapid development of fish culture in marine cages has been associated with an emergence of parasitic diseases (Fioravanti et al., 2006; Nowak, 2007). The difficulty of managing disease within sea-cages is regarded as a major drawback (Mladineo, 2006). Fish parasites are a major component of aquatic biodiversity, and their monitoring is considered an essential element of the management of the health for animals. Parasites that have low rates of infestation and minor pathological effects on their hosts under natural conditions can easily spread in populations confined to rearing systems, causing serious outbreaks and epizootics diseases resulting in significant economical losses (Combes, 1990; Ghittino et al., 2003; Johnson et al., 2004; Naylor et al., 2000). The environmental conditions in culture systems, in particular increased density of fish, repeated introduction of hosts, homogeneous host populations, fast growth and a potential decrease in genetic diversity have an important effect on commercial production 
and could prevent the expansion of the industry (FAO, 2010; Fernandez-Jover et al., 2010; Nowak 2007). Numerous studies on the parasites of marine fish were carried out, specifically on species with a great economical interest such as the European sea bass Dicentrarchus labrax or the Gilthead sea bream Sparus aurata (Antonelli et al., 2010a; Euzet \& Combes, 1998; Focardi et al., 2005; Reversat et al., 1992). They have long been recognized to have the potential to affect the survival of their hosts (Johnson et al., 2004). Investigations revealed that infections through the attachment of parasites and active feeding on mucus and epithelial cells of host fish by large populations can cause severe damages such as necroses, haemorrhages, inflammation, and mucus hyperproduction (Manera \& Dezfuli, 2003; Noga, 2000; Paperna \& Baudin Laurencin, 1979).

The European sea bass Dicentrarchus labrax, is one of the main marine fish species extensively reared in the Mediterranean area. It represents an important economical source, especially in Corsica. Fish production increases from 1000 tons in 1994 to 2250 tons today (Antonelli et al., 2009; Antonelli et al., 2010b).

They are many publications on the parasitofauna of cultured sea bass in various Mediterranean areas, where fish farming represents a significant economic activity (Cecchini et al., 1994; Johnson et al., 2004; Sitja-Bobadilla et al., 2006). Despite, the historical and commercial activities related to D. labrax in Corsica, few studies have been reported on their parasites. Investigations have revealed that many parasites species are globally frequent on this fish species, but large scales of mortality have not yet been registered (Antonelli et al., 2009; Antonelli, 2010).

The objective of the present study is to relate the occurrence of parasites to climatic conditions. Our survey aims to establish seasonal changes and spatial dynamics of parasites, and their importance for animal health for an improvement in the monitoring and management of populations of D. labrax of Corsica. The variation in the patterns of parasites communities was examined by taking into account environmental factors such as temperature, and physiological parameters related to host. Several studies have shown an increase of parasite richness with host age and that age and/or size related recruitment influenced parasite aggregation (Cable \& Van Oosterhout, 2007; Poulin \& Rohde, 1997; Silan, 1984). All animals are not equally infested according to their age. Our work will allow us to identify the most sensitive animals. Prevalence and abundances of the infections in different culture systems, fish stocks, and sampling seasons are reported.

\section{Materials and methods}

\subsection{Sampling and examinations}

A total of 470 European sea bass D. labrax from several culture systems on the South coasts of Corsica were sampled during the period ranging from January 2007 to December 2008. Fish were caught for parasitological examinations from six fish farms. Their names are not revealed for reasons of confidentiality: each farm is designated by a number (Figure 1). Seasonal samples varied from 10 to 15 specimens for each farm.

The production cycle of D. labrax cultured in Corsica is known. On average, larger prefattened sea bass (10 grams) reach first commercial size in about 1 year, while smaller juveniles (5 grams) reach the same size in about 16 months. Generally the fish are marketed 


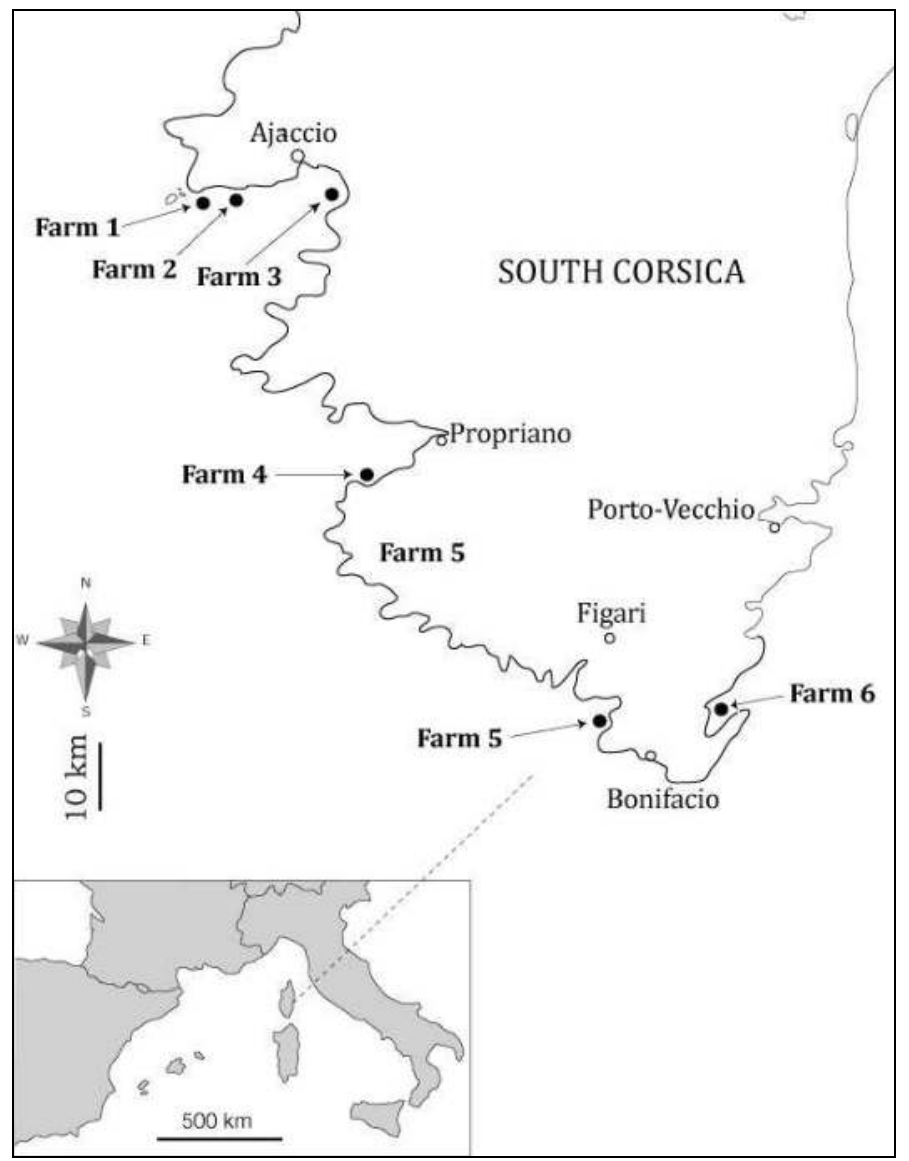

Fig. 1. Localisation of fish farms studied.

at age 2 years. In order to have consistent and significant results for a population we collected our samples still in the same cage for each farm throughout the study.

The fish were randomly collected directly from cages and immediately transported to the laboratory for analysis. Biometrical measures, sex and maturity stage of each specimen of $D$. labrax were recorded. Body surface (skin, fins) and gills of the fish were examined. Gill arches were carefully removed and studied in a fresh condition. The eight arches were separated (four right, four left) and immersed in Petri dishes containing seawater to replicate the best initial environmental conditions, and individually examined. Parasites were collected alive and immediately fixed in absolute ethanol. Parasites were identified using a light microscope according to the description done in previous studies (Cabral et al., 1984; Ozel et al., 2004; Toksen et al., 2008). Some specimens were fixed in glutaraldehyde to be studied in scanning electronic microscopy.

In order to asses the relationship of the infection with the host size and age, we considered two classes to discriminate younger from older fish. The first class (I) included fish under 30 
$\mathrm{cm}$ total length, and the second class (II) fish over $30 \mathrm{~cm}$. These classes were chosen taking into account the size ranged on sampled specimens. According to that study, classes would mainly include specimens with age $1+$ (I) and 2+ (II).

At each sampling, surface water temperature $\left({ }^{\circ} \mathrm{C}\right)$ and salinity $(\%)$ in cages was measured.

\subsection{Statistical analyses}

Relations between rates of infestation were investigated using statistical indices frequently used in ecology. Prevalence (proportion of the population infected), abundance (mean number of parasites of both infected and uninfected fish) and mean intensity (mean number of parasites of infected hosts) were calculated and applied according to Bush et al. (1997).

Statistical tests were conducted to determine the influence of several factors on the distribution of Lernanthropus kroyeri. Possible differences in infection parameters between seasons were evaluated using one-way analysis of variance. If data failed to meet parametric testing requirements, comparisons of the mean number of parasites found on $D$. labrax were performed using the Mann-Whitney $U$ test (two groups) and KruskalWallis test (more than two groups) according to Dagnelie (1975) and Sprent \& Ley (1992). Significance for all the statistical analyses was established with 95\% confidence intervals. Calculations were performed using the statistical software Systat 12 and SigmaStat 3.5. In order to be sure of our values we will then use the Bonferroni test which consists of correcting the mistake on the risk of alpha error when using the same test several times (Bland \& Altman, 1995).

\section{Results}

\subsection{Distribution of parasites in host population}

Five species of metazoan parasites included in four groups were identified: one monogenean Diplectanum aequans, two copepods, Lernanthropus kroyeri and Caligus minimus, one isopod Cerotothoa oestroides and the myxosporidian Ceratomyxa labracis.

$428(91.1 \%)$ of the $470 \mathrm{D}$. labrax examined were infected. The number of parasites per host ranged from 1 to 169. Externally, all fish used for the study appeared to be in good health, in body condition and in coloration. A total of 7376 parasites were collected. Water temperature varied from $13^{\circ} \mathrm{C}$ in winter to $24^{\circ} \mathrm{C}$ in summer (Fig. 2). Rates of salinity (\%o) are reported in table I.

\begin{tabular}{c|ccccccccc}
\hline Farms & \multicolumn{10}{|c}{ Seasons } \\
\hline & W2007 & S2007 & Su2007 & A2007 & W2008 & S2008 & Su2008 & A2008 & Mean values \\
$\mathbf{1}$ & 38.2 & 37.6 & 37.8 & 37.6 & 38.0 & 37.8 & 37.9 & 37.9 & 37.9 \\
$\mathbf{2}$ & 38.2 & 37.6 & 37.8 & 37.6 & 38.0 & 37.8 & 37.9 & 37.9 & 37.9 \\
$\mathbf{3}$ & 36.0 & 37.0 & 37.1 & 36.5 & 36.0 & 36.1 & 37.0 & 36.9 & 36.6 \\
$\mathbf{4}$ & 37.8 & 37.3 & 38.0 & 37.8 & 37.6 & 37.8 & 37.6 & 38.1 & 37.8 \\
$\mathbf{5}$ & 37.6 & 37.6 & 38.2 & 37.8 & 37.6 & 37.5 & 37.6 & 38.2 & 37.8 \\
$\mathbf{6}$ & 38.0 & 38.4 & 38.6 & 38.2 & 38.0 & 38.2 & 38.3 & 38.3 & 38.3 \\
\hline
\end{tabular}

Table 1. Seasonal rates of salinity (\%o) in all fish farms studied (W: winter; S: spring; Su: summer; A: autumn; 2007: first year of sampling; 2008: second year of sampling). 


\subsection{Presence of parasites in fish farms}

\subsubsection{Monogenea}

D. aequans was collected in all farms studied. 408 fish (86.8\%) were infected.

Farm 1: D. aequans occurred throughout the sampling period. Prevalence values varied from $50 \%$ to $90 \%$ (Figure 2). However, there is no statistically significant difference between seasons (Kruskal-Wallis, $\mathrm{p}<0.5$ ). The highest mean abundance value was recorded in winter. Values ranged from 4.2 to 10.4 during the study (Figure 3). The mean intensity shows the same trend as abundance with highest values recorded in autumn and winter (Figure 4). The infestation shows a clear seasonal pattern statistically verified with Kruskal-Wallis test ( $p<0.001)$.

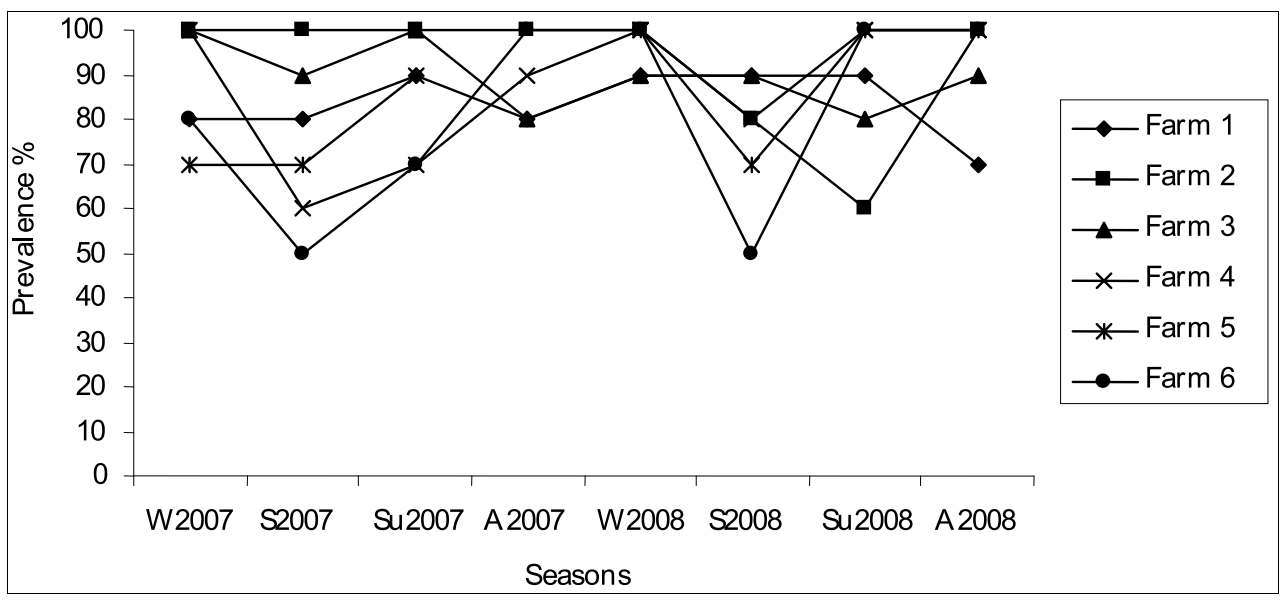

Fig. 2. Prevalence of Diplectanum aequans in fish farm studied according to season (W: winter; S: spring; Su: summer; A: autumn; 2007: first year of sampling; 2008: second year of sampling).

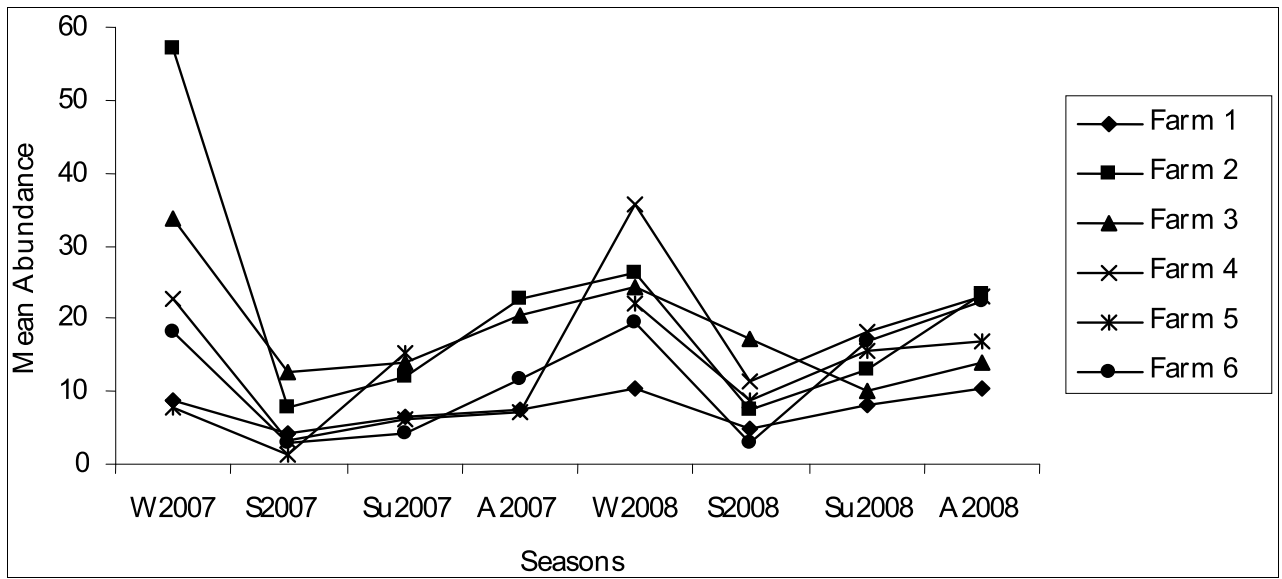

Fig. 3. Abundance of Diplectanum aequans in fish farm studied according to season (W: winter; S: spring; Su: summer; A: autumn; 2007: first year of sampling; 2008: second year of sampling). 
Farm 2: D. aequans were identified on all fish examined during the first year of study. After winter 2008, values sharply decreased to summer 2008 and increased gradually to autumn 2008 (Figure 2). The highest mean abundance was recorded in winter. Values ranged from 7.5 to 57.1 and the Kruskal-Wallis test shows a significant difference between seasons ( $\mathrm{p}<$ 0.001) (Figure 3). Mean highest intensity was recorded in winter (Figure 4) and statistically significant difference was revealed between spring and winter (Kruskal-Wallis, $p<0.001$ ).

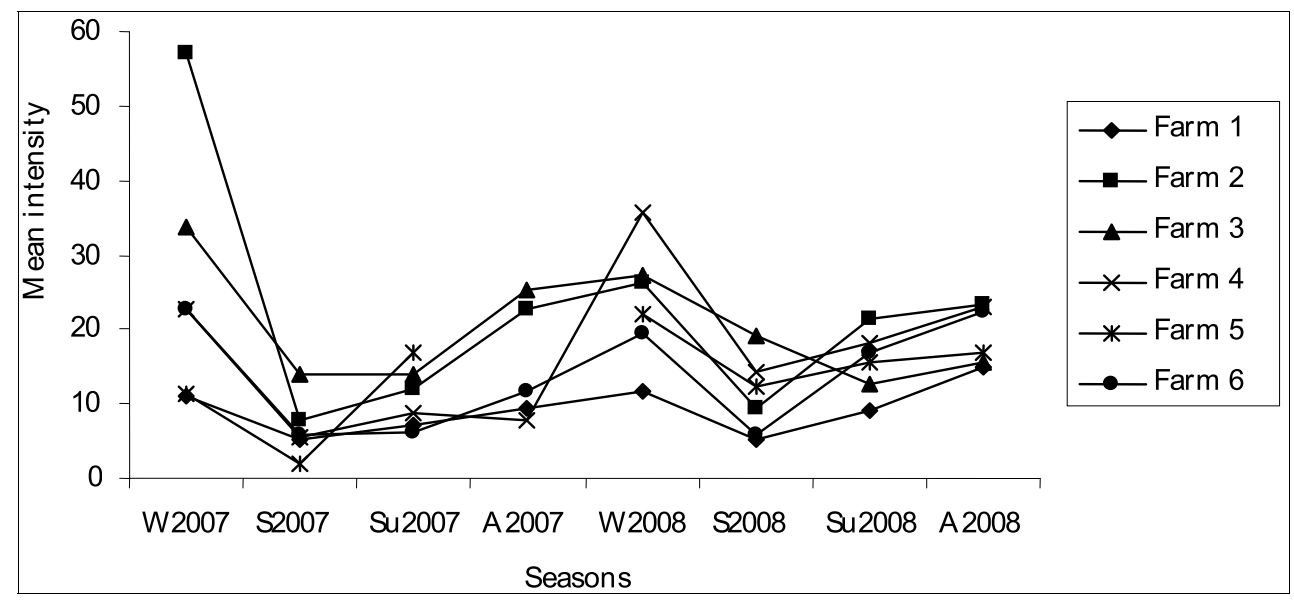

Fig. 4. Mean intensity of Diplectanum aequans in fish farm studied according to season (W: winter; S: spring; Su: summer; A: autumn; 2007: first year of sampling; 2008: second year of sampling).

Farm 3: the number of infected fish ranged from $80 \%$ to $100 \%$, with highest prevalence values recorded in winter (Figure 2). Mean abundance values ranged from 10 to 33.8 (Figure 3). Mann-Whitney $U$ test revealed significant difference between winter and spring ( $<<$ 0.001). The highest mean intensity values were recorded in winter and the lowest in summer (Figure 4). A statistically significant difference was revealed between winter and summer (Mann-Whitney $U$ test, $\mathrm{p}<0.001$ ).

Farm 4: prevalence values ranged from $60 \%$ to $100 \%$ (Figure 2). Abundances and intensity values are highest in winter and lowest in spring (Figure 3, 4). Statistically, significant difference was highlighted between spring and winter (Mann-Whitney $U$ test, $p<0.005$ ).

Farm 5: the number of infected ranged from 70\% to 100\% (Figure 2). The mean abundance and mean intensity show the same as prevalence with highest values recorded in winter (Figures 3, 4). However, no significant difference were found between seasons (KruskalWallis, $p=0.25$ ). In the case of farm 5 , it is difficult to analyze correctly data obtained during the sampling period because we had an interruption in our samples in autumn 2007.

Farm 6: prevalence values varied from $50 \%$ to $100 \%$, with highest values registered in autumn and winter and lowest in spring. After winter 2007, values decrease to spring 2007 and increase to autumn 2008; it decreases again in spring 2008 (Figure 2). The mean abundance was highest in autumn, with values ranging to 3 to 22.4 (Figure 3). The 
infestation shows a clear seasonal pattern verified with Kruskal-Wallis test $(p<0.001)$. The mean intensity show a similar trend to abundance with highest values recorded in autumn and winter (Figure 4), with a significant difference of seasonal infestation (Kruskal-Wallis, p $<0.001)$.

\subsubsection{Copepoda}

Specimens of L. kroyeri were collected only in the farm 6 . The investigations revealed the presence of parasites in $65 \%$ of D. labrax examined in this farm. A total of 283 specimens of L. kroyeri were collected (mean abundance: 3.7, mean intensity: 5.4). L. kroyeri occurred throughout the sampling period. The number of infected fish varied from $30 \%$ to $90 \%$ with highest prevalence values recorded in summer and lowest in winter (Figure 5).

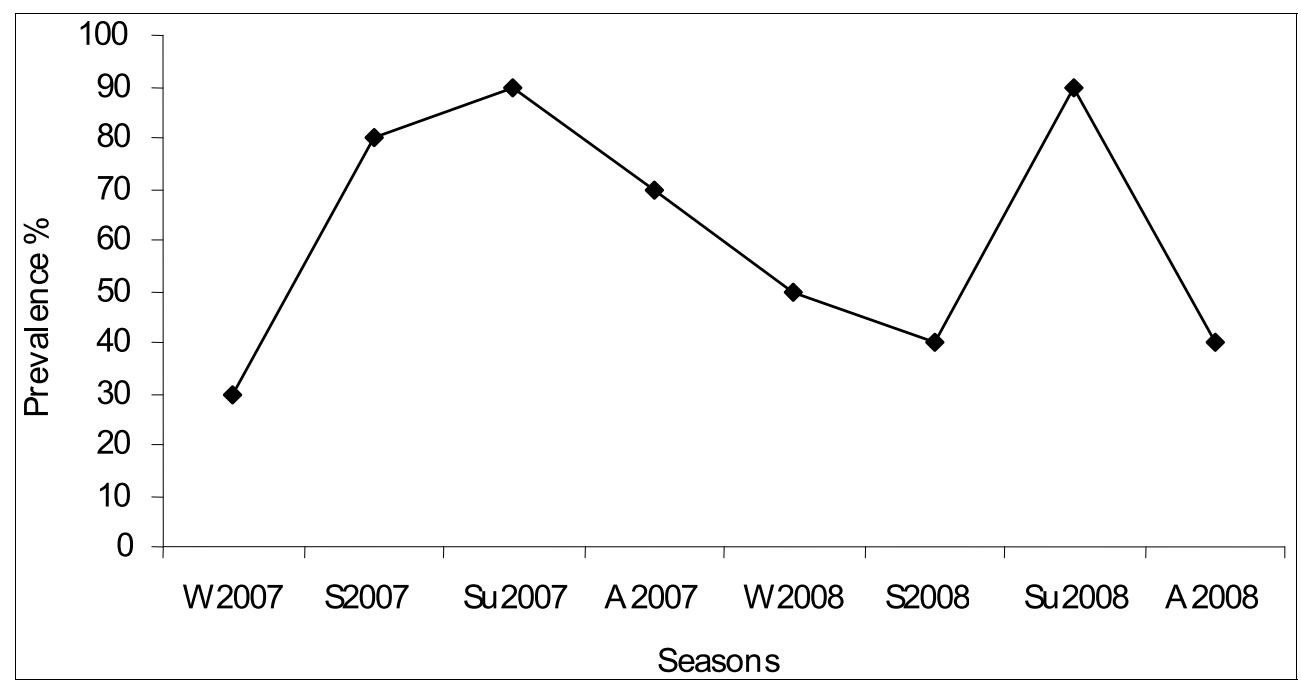

Fig. 5. Prevalence of Lernanthropus kroyeri in fish farm 6 according to season (W: winter; S: spring; Su: summer; A: autumn; 2007: first year of sampling; 2008: second year of sampling).

Mean abundance values ranged from 0.7 to 9.3 , and the highest values were recorded in spring 2007 separated by intervals of decreasing values, with a significant decline during winter 2008. After winter 2008, values sharply increased to summer 2008 (Figure 6).

The mean intensity shows the same trend as the abundance for the second year of study, with highest values recorded in summer (Figure 7). Statistically, the occurrence of infection showed a clear seasonal pattern verified with Kruskal-Wallis test $(p<0.001)$, with significant differences between winter and summer.

As L. kroyeri, C. minimus is identified only in the farm 6. Rates of infestations are lowest than those of L. kroyeri. Prevalence values ranged from 0 to $60 \%$ with highest values recorded in spring (Figure 8).

Abundance values shows that rates of infestation with $C$. minimus are relatively stable throughout the seasons, with an infestation a little more important for spring (Figure 9). 


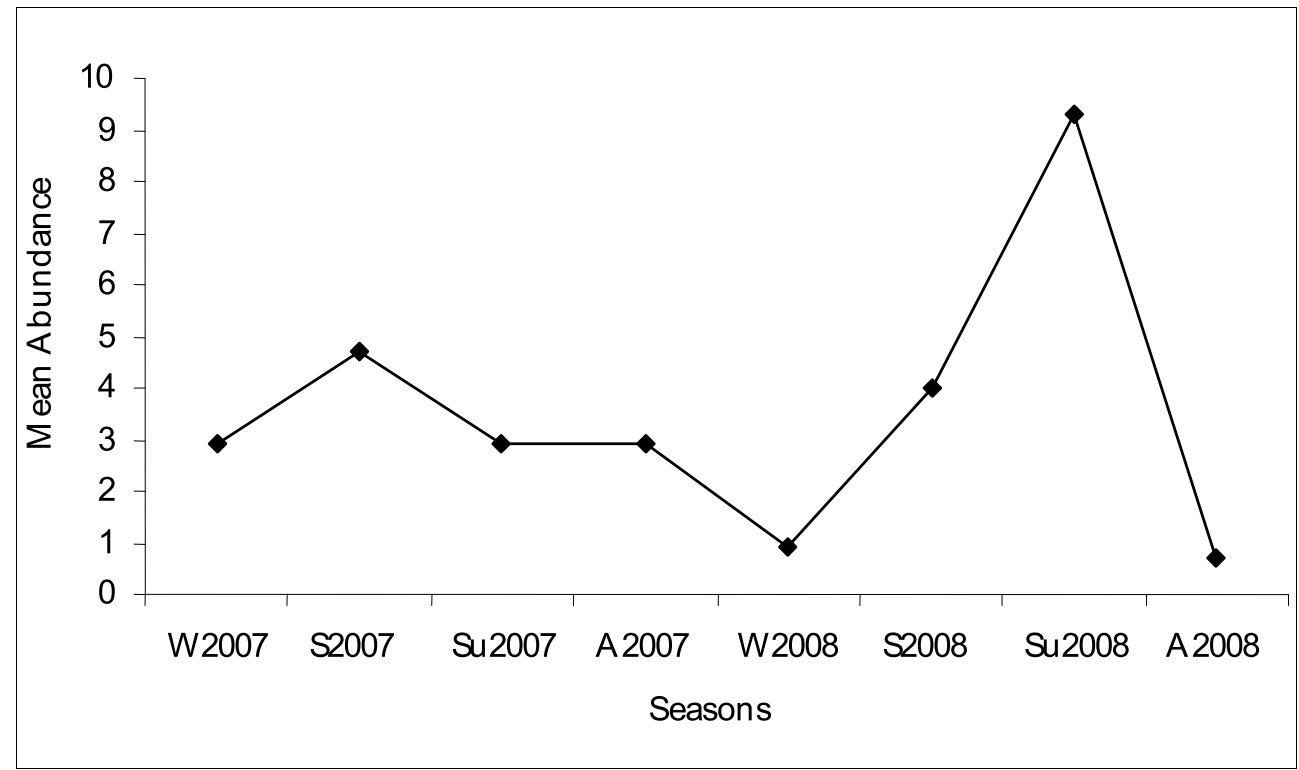

Fig. 6. Mean abundance of Lernanthropus kroyeri in fish farm 6 according to season (W: winter; S: spring; Su: summer; A: autumn; 2007: first year of sampling; 2008: second year of sampling).

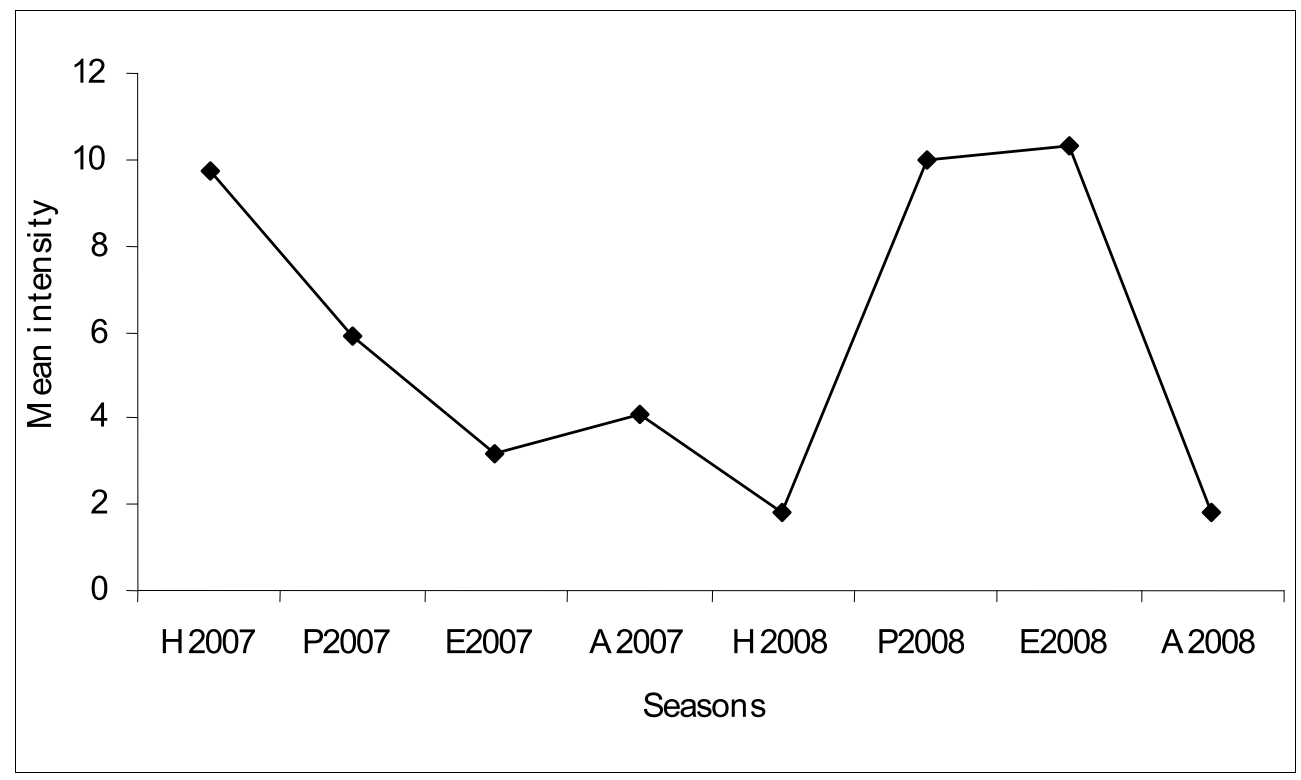

Fig. 7. Mean intensity of Lernanthropus kroyeri in fish farm 6 according to season (W: winter; S: spring; Su: summer; A: autumn; 2007: first year of sampling; 2008: second year of sampling). 


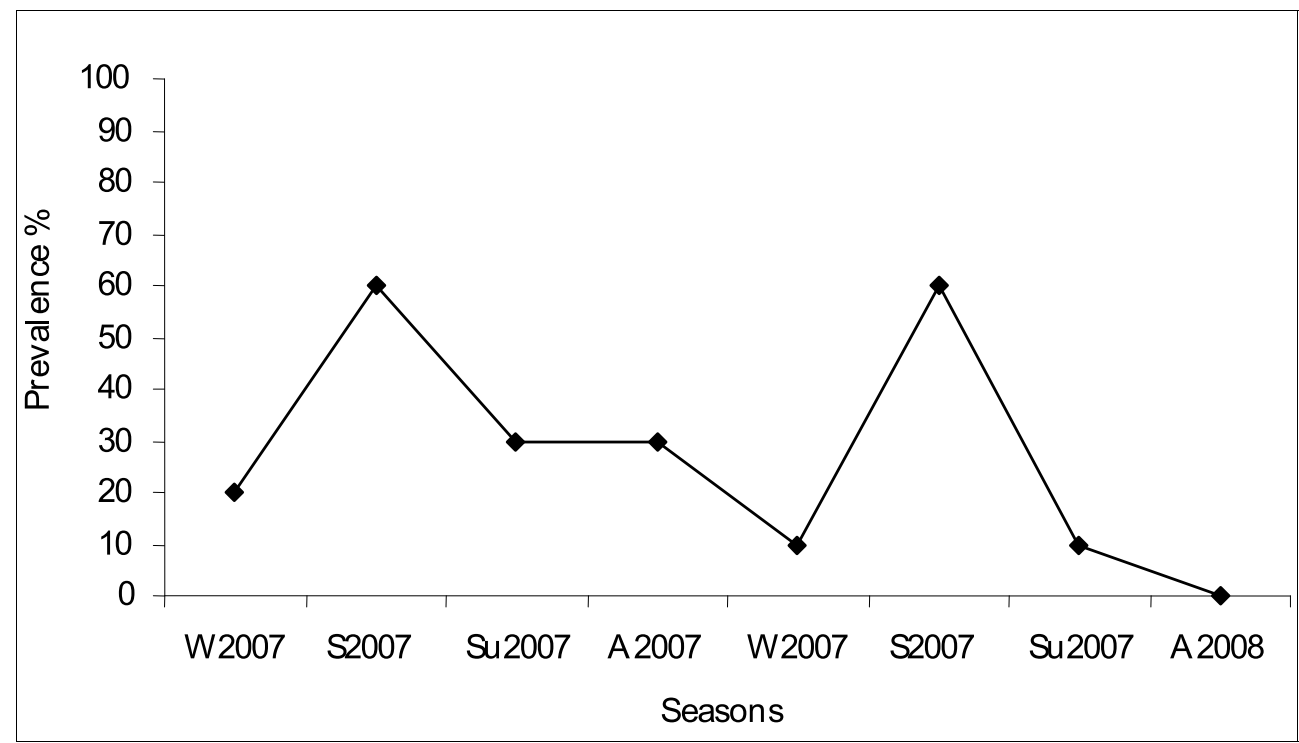

Fig. 8. Prevalence of Caligus minimus in fish farm 6 according to season (W: winter; S: spring; Su: summer; A: autumn; 2007: first year of sampling; 2008: second year of sampling).

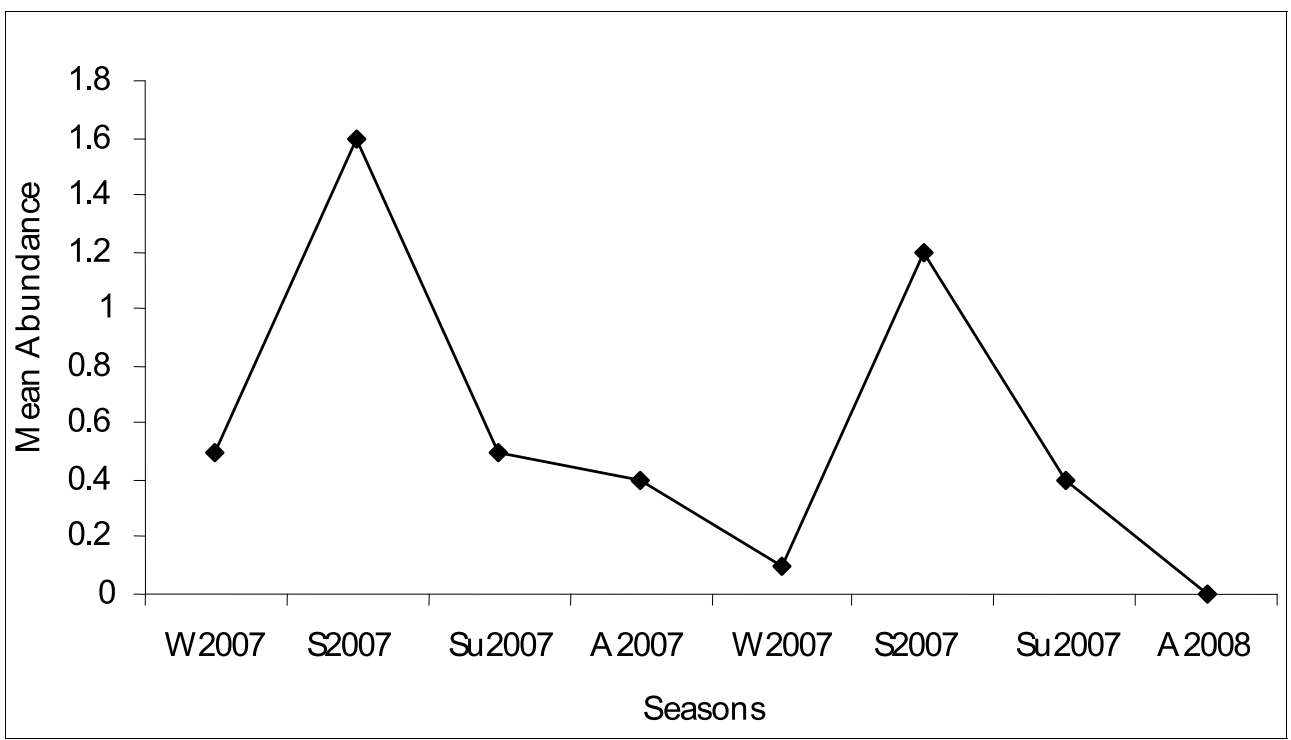

Fig. 9. Mean abundance of Caligus minimus in fish farm 6 according to season (W: winter; S: spring; Su: summer; A: autumn; 2007: first year of sampling; 2008: second year of sampling).

In 2008, the mean intensity increases with the elevation of water temperature. Highest values were recorded in spring and summer (Figure 10). However, no significant difference was revealed between season (Kruskal-Wallis, $\mathrm{p}=0.39$ ) because values are lower. 


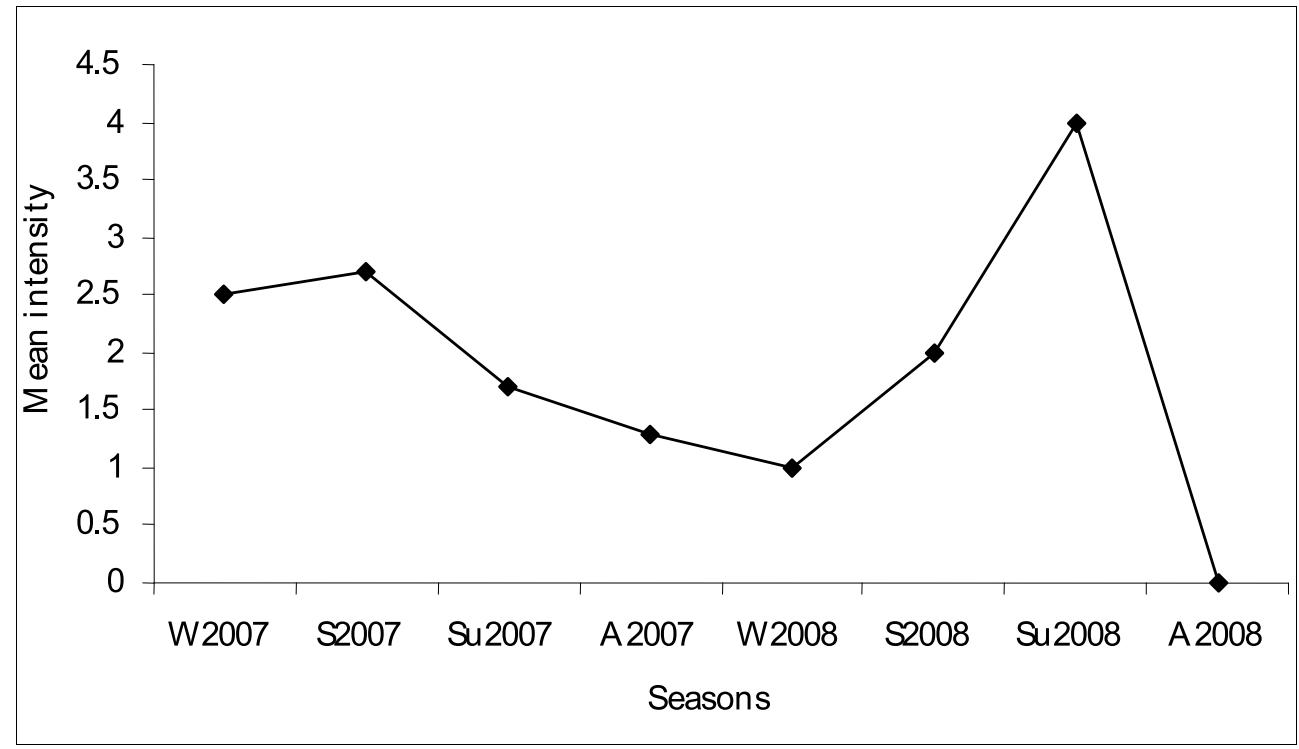

Fig. 10. Mean intensity of Caligus minimus in fish farm 6 according to season (W: winter; S: spring; Su: summer; A: autumn; 2007: first year of sampling; 2008: second year of sampling).

\subsubsection{Isopoda}

All specimens were found at the end of spring in 22 fish of the same farm. However, rates of infestation are to lower to have a significant result (prevalence: $4.7 \%$, mean abundance: 0.1 ).

\subsubsection{Myxosporea}

All specimens were found at the end of spring. As C. oestroides the number of parasites collected is to lower to have a significant result (prevalence: $0.43 \%$, mean abundance: 0.2 ). However, the study of mean intensity shows that in spite of the small number of infested fish C. labracis possesses highest value of mean intensity (69.04).

\subsection{Influence of the host size on parasite population}

\subsubsection{Monogenea}

The highest prevalence of $D$. aequans was registered for class II with $92 \%$. Class I possesses a lowest prevalence with $81 \%$. Our results showed an increase of mean abundances and mean intensities in the courses of generations. Values are higher for class II with 19.4 and 21.1 respectively. Statistical test show significant difference in abundances according to age classes (Kruskall-Wallis, $\mathrm{p}<0,001$ ). Older fish are more infested (Table 2).

\subsubsection{Copepoda}

Considering all samples as a whole, it was found that rates of infestation varied with host size. Results (prevalence, abundance and mean intensity) are presented in table 2. 
Concerning L. kroyeri, the lowest prevalence values were observed for class I (55\%) and the highest values for class II. The mean abundance and mean intensity have shown an irregular and significant pattern with size class (Kruskal-Wallis, $p=0.01$ ): values were higher in the largest specimens. Each size class corresponds to an age class. Class I represents younger fish while class II corresponds to the oldest fish. Rates of infestation were relatively similar but values of mean abundance and mean intensity showed that larger and older fish tend to be more parasitized.

Prevalence values of $C$. minimus increase between class I and class II. Older fish are more infected. However, there is no significant difference between age classes (Kruskal-Wallis, $\mathrm{p}$ $=0.237)$. Mean abundance and mean intensity show values relatively close between generations.

\begin{tabular}{c|ccccc}
\hline $\begin{array}{c}\text { Parasites } \\
\text { species }\end{array}$ & Age class & $\begin{array}{c}\text { N Fish } \\
\text { examined }\end{array}$ & Prevalence \% & $\begin{array}{c}\text { Mean } \\
\text { abundance }\end{array}$ & $\begin{array}{c}\text { Mean } \\
\text { Intensity }\end{array}$ \\
\hline D. aequans & $1+$ & 210 & 81 & 9 & 11 \\
& $2+$ & 260 & 92 & 19.4 & 21.1 \\
L. kroyeri & $1+$ & 33 & 55 & 1.7 & 3.1 \\
& $2+$ & 47 & 72.3 & 4.8 & 6.7 \\
C. minimus & $1+$ & 33 & 21.2 & 0.3 & 1.3 \\
& $2+$ & 47 & 32 & 0.8 & 2.5 \\
\hline
\end{tabular}

Table 2. Rates of infestation of D. labrax between age classes.

\subsubsection{Isopoda}

Four parasites were collected. The number of parasites is too low to establish a relation between infestation and host age.

\subsubsection{Myxosporea}

Colonies of $C$. labracis were collected in the stomach of two fish. A total of 120 colonies were counted (prévalence: $1 \%$, abundance: 0.5 ) but our data are not sufficient to establish a hypothesis between host age and the number of parasites.

\section{Discussion}

\subsection{Distribution of parasites in host population}

The relationship of the number of parasites to severity of disease can be dependent of some factors. A variety of environmental and biological factors and management practices that may influence rates of infestation of parasites have been identified. Parameters including oceanographic factors (temperature or water circulation) associated with physiological factors (immunological alterations and hormonal changes) are the most frequent causes suggest to explained seasonal fluctuations of parasitic infections. They are highly variable and may vary seasonally or annually (Gonzalez-Lanza et al., 1991, Oliver, 1982; Robertsen et al., 2008; Winger et al., 2008). 


\subsection{Presence of parasites in fish farms}

Seasonal fluctuations in prevalence and abundance are common in many parasites species infecting marine fish (Oliver, 1982). Our results indicated pronounced changes in the cycle of infection, with variation in parasite distribution. The fluctuation in rates of infestations showed that water temperature, which generates a definite seasonal cycle, has a great influence on the population dynamics of parasites. Many studies conducted on the behaviour of parasites in culture conditions have shown that water temperature is the major abiotic factor affecting reproduction and population growth (Oliver, 1987). Generally, high water temperature levels promote faster hatching of eggs and parasites propagate rapidly (Gannicott \& Tinsley, 1998; Kim et al., 2001; Silan \& Maillard, 1989). Cyclic peaks of many parasites species have been mainly registered in sea cages during summer months (Andersen and Buchmann, 1998; Cecchini et al., 1998; Gelnar, 1987).

As monogeneans, in contrast to other helminths, which need intermediate hosts to complete their life cycle, have a direct life cycle, temperature appears to be the most significant in explaining the seasonal periodicities. Generally, monogeneans propagate rapidly on the host fish in warm water seasons. Our results differ in some extent from those reports in the Mediterranean. This study demonstrates that transmission of D. aequans in fish farms is seasonal, with invasion maximized during the colder part of the year and almost negligible infection over summer. Influence of temperature causing a rapid development on the life cycle of D. aequans was reported in D. labrax. Cecchini (1994) mentioned that between $20^{\circ} \mathrm{C}$ and $30^{\circ} \mathrm{C}$, hatching of $D$. aequans takes place a few days after laying, whereas at $15^{\circ} \mathrm{C}$ and $10^{\circ} \mathrm{C}$ it occurs respectively between the $11^{\text {th }}$ and the $19^{\text {th }}$ day. However, the present study revealed that $D$. aequans exhibit clear and significant seasonal changes with highest rates of infestation recorded in winter and the lowest during summer, following a contrary temperature pattern. These variations tend to confirm that $D$. aequans display spatial and temporal stability. Similar data has already been reported for some monogeneans, including D. aequans, and may be explained by changes in parasites behaviour (Antonelli, 2010; Robertsen et al., 2008; Silan, 1984). These results may indicate that D. aequans is adapted to cold temperature. Lambert \& Maillard (1974) and Gonzalez-Lanza et al., (1991) demonstrated that seasonal changes in composition of parasites population of D. labrax could be the sign of a parasitic adaptation, and suggest continuous recruitment and their persistence throughout the year.

Temperature is also assumed to influence the immune defence in fishes, and may affect intensities of parasites indirectly (Johnson et al., 2004; Oliver, 1982). Variations in rates of infestation through the seasons can also be explained by changes in the fish behaviour. Abundance peak recorded in winter for $D$. aequans can coincide with an immunodeficiency of fish linked to brutal changes in temperature during the transition from autumn to winter (Faliex et al., 2008). These periods of decreasing of water temperature result in a stress response of the European sea bass (Hadj Kacem et al., 1987). This may reflect a weakened immune system of fish, and therefore a greater vulnerability, leaving the opportunity for parasites to increase their populations rapidly (Oliver, 1982).

Results found for copepod species L. kroyeri agree with data previously reported in the Mediterranean (Bahri et al., 2002; Manera \& Dezfuli, 2003). The development of L. kroyeri appears to be directly linked to water temperature; highest rates of infestation were recorded in spring and summer, coinciding with an increase of water temperature. Seasonal 
changes in prevalence and abundance suggest that L. kroyeri have an annual life cycle, with one period of heavy infestation. Like most copepods, L. kroyeri have a direct life cycle and environmental factors such as temperature appears to be the most significant in explaining the seasonal periodicities (Noga, 2000). Host tissue reactions were observed on gill filaments in the immediate vicinity of the copepod attachment sites. This hyperplasia or inflammation of gill tissue is interpreted as a host tissue immune response to parasite aggression.

C. minimus, C. oestroides and C. labracis were identified in our study but rates of infestation appear very low. Two hypotheses are considered to explain these results:

- The fish is adapted to the presence of these parasites species and rates of infestation decreased as it was already demonstrated by Mladineo \& Marsic-Lucic (2007) for the Gilthead sea bream Sparus aurata ;

- This lowest infestation explains by a recent arrival of the parasites in the environment.

Only a long-term surveillance would allow us to verify these hypotheses.

Specimens of $C$. oestroides and C. labracis have been collected in the same fish farm, but our data values are too low to comment statistically our results. However, the presence of these isolated individuals could be the result of a parasitic transfer. Numerous wild fish revolved all around cages looking for food. There is an international speculation that parasite transmission from farmed to wild fish leads to increase the incidence of parasitism in wild fish. However, our previous study tend to confirm that some diseases are transmitted directly to fish by cohabitation with infected fish or by horizontal transmission from wild marine fish. The analyse of the parasitic fauna of wild fish living around cages highlighted important rates of infestation with C. oestroides (Antonelli et al., 2009; Antonelli 2010). Wild fish are believed to be the primary reservoirs of parasites infection for fish farmed in sea-cages, and can negatively impact upon the health of farmed fish (Bragoni et al., 1984; Hutson et al., 2007). In our case, D. labrax can constitute a new host to colonize for new parasites species. Physiological parameters of some parasites species, e.g. female C. oestroides constantly mature, could entrain a rapid parasitic development, causing highest mortalities (Bragoni et al., 1984).

A few studies highlighted infestation with myxosporean in D. labrax. Alvarez-Pellitero \& Sitjà-Bobadilla (1993) mentioned that infestation due to C. labracis is more important in cultured fish than in wild fish. The infestation in fish farm 5 is relatively low but it must be controlled. C. labracis is highly pathogen and can provoke serious outbreaks on fish, such as inflammatory reaction of epithelial cells.

Our observations were also consistent with the idea that local conditions can influence rates of infestation. The high densities living conditions in sea-cages can favour parasites infestation, and fish became targets for infection at high levels. Parasites having low rates of infestation in the wild can easily spread in populations confined to rearing systems. This phenomenon is partly due to the direct biological cycle of parasites without intermediate host (Buchmann and Lindenstrøm, 2002; Fioravanti et al., 2006; Hayward et al., 2007). They are likely to establish and proliferate in aquaculture because they may reproduce rapidly (Hutson et al., 2007). The presence of parasites throughout the year may be due to close and prolonged contact between fish in the same cage (Mladineo, 2006).

In addition to the season, the presence of copepods in a single farm suggests that several factors may operate in the distribution of this parasite, but also the location of the farm. The 
fact that the farm 6 was isolated on the East coast of Corsica may not have allowed the parasite to infect other farms. The presence of copepods on a single farm, could explain according to salinity. The farm 6 is situated in a zone of shallow depth. In littoral waters (some tens of meters) the contributions of continental fresh water generate vertical stratifications which can modify the parameters of temperature and salinity (Aminot \& Kerouel, on 2004). This difference could also be due to the circulating sea currents around the island, in particular the Liguro-Provençal current. This one goes raises of Sicily towards French coasts, by the canal to Corsica, situated on the eastern coast, with waters of surface charged in minerals. In the Gulf of Lions, these waters are then going to mix with waters of the western Mediterranean Sea, much less salted.

Copepods require concentrations in salt less important than monogeneans (Devreker et al., 2009; Mc Allen \& Brennan, 2009). We can suppose that monogeneans are thus less present in the fish farm 6 because the environment is less salty than on the western coast. It also coincides with the results obtained for the monogenea $D$. aequans in the fish farm 3 and suggests that the salinity could be a factor conditioning the presence or the absence of certain parasites of D. labrax in Corsica.

Heavy rates of infestation could result also of breeding conditions. Highest densities and thus contact between fish in cages could favor the apparition and development of pathogens (Combes, 1990; Johnson et al., 2004; Nowak, 2007; Sterud, 2002). While there are speciesspecific differences in optimum stocking density intensively cultured fish are usually kept at greater densities than occur in the wild. This increases host proximity and therefore improves the ability of a parasite to locate a host. High densities in cages can also promote a parasite infestation. For example, sea bass showed higher stress levels at high densities resulting on chronic stress situation and innate immune response favouring parasites development (Vazzana et al., 2002).

The introduction of a new species in an ecosystem without sanitary control could constitute a serious risk of parasites transfer responsible for the break of for the break of natural hostparasite interactions (Euzet \& Pariselle, 1996). In mariculture, naive fish are introduced from hatcheries to sea cages and can increase the frequency of infections. Intensive aquaculture of fish is not without its problems, and these include disease outbreaks and consequences of introducing parasites to new host and/or new localities with the transportation of live fish (Combes, 2001). Severe epizootic periods have occurred because of fastest accumulation of pathogens in fish populations.

\subsection{Influence of the host size on parasite population}

We found significant relationships between the parasite burden and host-related factors. Dominant parasites species showed a positive relationship between host age/size and parasite load. Rates of infestation (prevalence, abundance and intensity) showed significant changes with host age/size (body length is closely related to age in fish). Older fish are more parasitized. This positive correlation between age (and therefore the size) of fish abundance and parasite occurs relatively frequently for different fish parasites including monogeneans (Cable \& Van Oosterhout, 2007; Poulin \& Rohde, 1997). A higher parasitisation level in older fish has also been observed by Silan (1984) for D. aequans. Our results for copepods differ from those reported by Manera \& Dezfuli (2003), which reported that small fish are more 
parasitised than large, but prevalence of copepods increased with host size up to fish of intermediate length before decreased.

The influence of host age and/or size on parasites populations has been demonstrated by several authors, and two hypotheses have been proposed to explain these relationships.

- The first hypothesis followed the island size hypothesis, which is also linked to the "theory of island biogeography" proposed by Mac Arthur \& Wilson (1967). Dogiel (1964) compared the host to an island and concluded that the larger the host, the more parasites can settle on it.

- The second hypothesis refers directly to host age. Host accumulates parasites as they get older because time increases the likelihood of acquiring parasites.

Previous studies showed that the variation of the parasitism depending on the size and age of fish can be depending on several factors. The availability of space may be one of these factors involved in the infection of European sea bass. The abundance of gill-infecting parasites has been correlated to host size, where an increase in body length is accompanied by modification in gill surface. An increase in the branchial surface can provide a larger area of infestation, and thus more potential sites for attachment of these parasites (El Madhi \& Belghyti, 2006). Changes in size of gills filaments were associated with an increase of the volume of water passing through the gill cavity, may affect attachment capability of parasites and enhancing the possibility of being detached by respiratory currents (Timi \& Lanfranchi, 2006). Parasites were attached horizontally, facing into a seawater flow supplied by a circulating water system. This may indicate that only the most resistant parasites can be securely attached to a fish of a given size, and may influence transmission, increasing or decreasing the chances of invasion by the larvae of parasites (Buchmann \& Lindenstrøm, 2002). Also, in their natural environment, larger individuals have higher physical (ventilation volume) or chemical (mucus) stimuli which increase their attractiveness to parasites (Kearn, 1967). showed that copepods were able to respond to visual and mechanical cues by increasing their swimming activities. All of these factors should logically increase the probability of encountering free infective stages.

\section{Conclusion}

Even though the overall prevalence was higher, parasites were never abundant in our study. Mortalities related to parasites were not reported and all fish examined appear to be in good health. Our results differ in some extent from those reported by Manera \& Dezfuli (2003) who reported clinical signs such as occlusion of branchial circulation, destruction of gills and massive mucus cell proliferation observed on fish. Fish sampled during our work do not display the symptoms described in previous studies (Manera \& Dezfuli, 2003; Toksen et al., 2008). Parasites were present at too low abundances and intensities to affect the health of cultured sea bass. However, we must remain vigilant and we have to monitor the evolution of the parasite. We expect that the parasites infection scenarios reported here illustrate basic characteristics of the host-parasite interaction and would correspond with infection regimes affecting fish farms at different times of the year. The fact that transmission is seasonal will allow the introduction of measures to decrease parasite recruitment. 


\section{References}

Alvarez-Pellitero, P. \& Sitjà-Bobadilla , A. (1993). Ceratomyxa spp. (Protozoa, Myxosporea) infections in wild and cultured se bass, Dicentrachus labrax, from the Spanish Mediterranean area. Journal of fish biology, Vol. 42, No. 6 (June 1993), pp. (889-901), ISSN 1095-8649.

Aminot, A. \& Kerouel, R. (2004). Hydrologie des écosystèmes marins: paramètres et analyses. Collection Méthodes d'analyse en milieu marin, IFREMER, pp. 336.

Andersen, P.S \& Buchmann, K. (1998). Temperature dependent population of Gyrodactylus derjavini on rainbow trout Oncorhynchus mykiss. Journal of Helminthology, Vol. 72, No. 1 (March 1998), pp. (9-14), ISSN 0022-149X.

Antonelli, L. (2010). Impact du parasitisme sur la pisciculture en Corse. Suivi des parasitoses et étude des transferts de parasites depuis la faune sauvage vers les poisons élevés en mer ouverte. Thèse, pp. 254.

Antonelli, L., Ternengo, S., Agostini, S. \& Marchand, B. (2009). Suivi parasitaire des fermes aquacoles de Corse (campagnes 2007-2008). Action collective, Contrat Syndicat des Aquaculteurs Corses / Université de Corse. Université de Corse, pp. 47.

Antonelli, L., Quilichini, Y. \& Marchand, B. (2010a). Sparicotyle chrysophrii (Van Beneden and Hesse 1863) (Monogenea: Polyopisthocotylea) parasite of cultured Gilthead sea bream Sparus aurata (Linnaeus 1758) (Pisces: Teleostei) from Corsica: ecological and morphological study. Parasitology Research, Vol. 107, No. 2 (April 2010), pp. (389398), ISSN: 0932-0113.

Antonelli L., Quilichini Y. \& Marchand B. (2010b). Biological study of Furnestinia echeneis Euzet and Audoin 1959 (Monogenea: Diplectanidae), parasite of cultured Gilthead sea bream Sparus aurata (Linnaeus 1758) (Pisces: Teleostei) from Corsica. Aquaculture, Vol. 307, No. 3-4 (September 2010), pp. (179-186), ISSN 0044-8486.

Ashley, P.J. (2006). Fish welfare: Current issues in aquaculture. Applied Animal Behaviour Science, Vol. 104, No. 3-4 (May 2007), pp. (199-235) ISSN 0168-1591.

Bahri, L., Ben Hamida, J. \& Ben Hassine, O.K. (2002). Use of parasitic copepod, Lernanthropus kroyeri (Van Beneden, 1851) (Lernanthropidae) as bio-indicator of two fish populations, Dicentrarchus labrax (Linnaeus, 1758) and Dicentrarchus punctatus (Bloch, 1792) (Moronidae) in Tunisian inshore areas. Crustaceana, Vol. 75, No. 3-4 (March-April 2001), pp. (253-267), ISSN 0011-216X.

Basurco, B. \& Lovatelli, A. (2005). The aquaculture situation in the Mediterraneans sea: predictions for the future, Retrieved from http:/ / www.iasonnet.gr./abstract/ Basurco.pdf.

Bland, J.M. \& Altman, D.G. (1995). Multiple significance tests: the Bonferroni method. British Medical Journal, Vol. 310, No. 6973 (January 1995), pp. 170, ISSN 0959-8146.

Bragoni, G., Romestand, B. \& Trilles, J.P. (1984). Parasitoses à Cymothoadiens chez le loup Dicentrarchus labrax (Linneaus, 1758) en élevage. 1. Ecologie parasitaire dans le cas de l'étang de Diana (Haute-Corse) (Isopoda, Cymothoidae). Crustaceana, Vol. 47, No. 1 (January 1984), pp. (44-51), ISSN 0011-216X.

Buchmann, K. \& Lindenstrøm, T. (2002). Interactions between monogenean parasites and their fish hosts. International Journal for Parasitology, Vol. 32, No. 3 (March 2002), pp. (309-319), ISSN 0020-7519. 
Bush, A.O., Lafferty, K.D. \& Lotz, J.M. (1997). Parasitology meets ecology on its own terms: Margolis et al. revisited. Journal of Parasitology, Vol. 83, No. 4 (August 1997), pp. (575-583), ISSN 0022-3395.

Cable, J. \& Van Oosterhout, C. (2007). The impact of parasites on the life history evolution of guppies (Poecilia reticulate): the effects of host size on parasite virulence. International Journal for Parasitology. Vol. 37, No. 13 (November 2007), pp. (14491458), ISSN: 0020-7519.

Cabral, P., Coste, F. \& Raibaut, A. (1984). Cycle évolutif de Lernanthropus kroyeri (Van Beneden, 1851) Copépode branchial du loup Dicentrarchus labarx (Linné, 1758) dans des populations naturelles et en élevage. Annales de Parasitologie Humaine et Comparée, Vol. 59, No. 2, pp. (189-207), ISSN 0003-4150.

Cecchini, S. (1994). Influence of temperature on the hatching of eggs of Diplectanum aequans, a parasite of sea bass. Aquaculture International, Vol. 2, No. 4 (November 1994), pp. (249-253), ISSN 0967-6120.

Cecchini, S., Saroglia, M., Berni, P. \& Cognetti-Varriale, A.M. (1998). Influence of temperature on the life cycle of Diplectanum aequans (Monogenea, Diplectanidae), parasitic on sea bass, Dicentrarchus labrax (L.). Journal of Fish Diseases, Vol. 21, No. 1 (January 1998), pp. (73-75), ISSN 0140-7775.

Combes, C. (1990). When is a parasite pathogen? Metazoan parasitic diseases: concluding remarks. In: Pathology in marine science, Academic Press Inc. Publisher, pp. (331-340).

Combes, C. (1995). Interactions durables. Ecologie et évolution du parasitisme. Ed. Masson, Paris, collection écologie. 523 pp., ISBN: 2-10-005753-7.

Dagnelie, P. (1975). Analyses statistiques à plusieurs variables, Presses agronomiques de Gembloux, Bruxelles. 362 pp., ISBN 978-2-87016-019-0.

Devreker, D., Souissi, S., Winkler, G., Forget-Leray, J. \& Leboulenger, F. (2009). Effects of salinity, temperature and individual variability on the reproduction of Eurytemora affinis (Copepoda; Calanoida) from the Seine estuary: A laboratory study. Journal of Experimental Marine Biology and Ecology, Vol. 368, No.2 (January 2009), pp. (113-123) ISSN 0022-0981.

Dogiel, V.A. (1964). General parasitology. Translation 1.2, Kabata, Oliver and Boyd, Edinburgh and London. $516 \mathrm{pp}$.

El Madhi, Y., Belghyti, D. (2006). Distribution de deux Monogènes dans les individus hôtes de Trachinotus ovatus (L, 1758) de la côte de Mehdia. Biologie et Santé, Vol. 6, No.2, pp. (65-76).

Euzet, L. \& Combes, C. (1998). The selection of habitats among the monogenea. International Journal for Parasitology, Vol. 28, No. 10 (October 1998), pp. (1645-1652), ISSN 00207519.

Euzet, L. \& Pariselle, A. (1996). Le parasitisme des poissons Siluroidei: un danger pour l'aquaculture? Aquatic Living Resources, Vol. 9, supplement S1 (Special Edition: The biology and culture of catfishes) (November 1996), pp. (145-151), ISSN 0990-7440.

Faliex, E., Da Silva, C., Simon, G. \& Sasal, P. (2008). Dynamic expression of immune response genes in the sea bass Dicentrarchus labrax experimentally infected with the monogenean Diplectanum aequans. Fish and Shellfish Immunology, Vol. 24, No. 6 (June 2008), pp. (759-767) ISSN 1050-4648.

FAO. (2010). Food and Agriculture Organization of the United Nations: State of world aquaculture. 197 pp., ISSN 1020-5489. 
Fernandez-Jover, D., Faliex, E., Sanchez-Jerez, P., Sasal, P. \& Bayle-Sempere, J.T. (2010). Coastal fish farming does not affect the total parasite communities of wild fish in SW Mediterranean. Aquaculture, Vol. 300,No 1-4 (February 2010), pp. (10-16), ISSN 0044-8486.

Fioravanti, M.L., Caffara, M., Florio, D., Gustinelli, A., Marcer, F. \& Quaglio, F. (2006). Parasitic diseases of marine fish: epidemiological and sanitary considerations. Parassitologia, Vol. 48, No. 1-2 (June 2006), pp. (15-18), ISSN 0048-2951.

Focardi, S., Corsi, I. \& Franchi, E. (2005). Safety issues and sustainable development of European aquaculture: new tools for environmentally sound aquaculture. Aquaculture International, Vol. 13, No. 1-2 (January 2005), pp. (3-17), ISSN 0967-6120.

Gannicott, A.M. \& Tinsley, R.C. (1998). Larval survival characteristics and behaviour of the gills monogenean Discocotyle sagittata. Parasitology, Vol. 177, No. 5 (November 1998), pp. (491-498), ISSN 0031-1820.

Ghittino, C., Latini, M., Agnetti, F., Panzieri, C., Lauro, L., Ciapelloni, R. \& Petracca, A. (2003). Emerging pathologies in aquaculture: effects on production and food safety. Veterinary Research Communication, Vol. 27, supplement 1, pp. (471-479) ISSN 01657380.

Gonzalez-Lanza, C., Alvarez-Pellitero, P. \& Sitjà-Bobadilla, A. (1991). Diplectanidae (Monogenea) infestations of sea bass, Dicentrarchus labrax (L.), from the Spanish area. Histopathology and population dynamics under culture conditions. Parasitology Research, Vol. 77, No. 4 (April 1991), pp. (307-314), ISSN 0932-0113.

Gelnar, M. (1987). Experimental verification of the effect of water temperature on micropopulation growth of Gyrodactylus katharineri Malmberg, 1964 (Monogenea) paraziting carp fry (Cyprinus carpio L.). Folia Parasitologica, Vol. 34, No. 1 (JanuaryFebruary 1987), pp. (19-23), ISSN 0015-5683.

Guo, F.C. \& Woo, P.T.K. (2009). Selected parasitosis in cultured and wild fish. Veterinary Parasitology, Vol. 163, No 3 (August 2007), pp. (207-216), ISSN 0304-4017.

Hadj Kacem, N.H., Aldrin, J.F. \& Romestand, B. (1987). Effets immediats d'une augmentation rapide de temperature sur certains parameters sanguins du loup, Dicentrarchus labrax. Aquaculture, Vol. 64, No. 4 (August 1987), pp. (325-331), ISSN 0044-8486.

Hayward, C.J., Aiken, H.M. \& Nowak, B.F. (2007). Metazoan parasites on gills of Southern Bluefin Tuna (Thunnus maccoyii) do not rapidly proliferate after transfer to sea cages. Aquaculture, Vol. 262, No. 1 (February 2007), pp. (10-16), ISSN 0044-8486.

Hutson, K.S., Ernst, I. \& Whittington, I.D. (2007). Risk assessment for metazoan parasites of yellowtail kingfish Seriola lalandi (Perciformes: Carangidae) in South Australian sea-cage aquaculture. Aquaculture, Vol. 271, No. 1-4 (October 2007), pp. (85-99), ISSN 0044-8486.

Kearn, G.C. (1967). Experiments on host-findings and host-specificity in the monogenean skin parasite Entobdella soleae. Parasitology, Vol. 57, No. 3 (August 1967), pp. (585605), ISSN 0031-1820.

Kim, K.H., Ahn, K.J. \& Kim, C.S. (2001). Seasonal abundances of Prosomicrocotyla gotoi (Monogenea) and Opecoelus sphaericus (Digenea) from greenlings Hexagrammos otakii in a southern coastal area in Korea. Aquaculture, Vol. 192, No. 2-4, (January 2001), pp. (147-153), ISSN 0044-8486. 
Johnson, S.C., Treasurer, J.W., Bravo, S., Nagasawa, K. \& Kabata, Z. (2004). A review of the impact of parasitic Copepods on marine aquaculture. Zoological Studies, Vol. 43, No. 2 (April 2004), pp. (229-243), ISSN 1021-5506.

Lambert, A. \& Maillard, C. (1974) (Monogenea, Monopisthocotylea) parasites simultanés de Dicentrarchus labrax (Téléostéen). Annales de Parasitologie Humaine et Comparée, Vol. 50, pp. (691-699), ISSN 0003-4150.

MacAllen, R. \&, Brennan, E. (2009). The effect of environmental variation on the reproductive development time and output of the high-shore rockpool copepod Tigriopus brevicornis. Journal of Experimental Marine Biology and Ecology, Vol. 368, No. 1 (January 2009), pp (75-80), ISSN 0022-0981.

MacArthur, R.H. \& Wilson, E.O. (2001). The theory of island biogeography. Princeton, New Jersey.: Princeton University Press.

Manera, M. \& Dezfuli, B.S. (2003). Lernanthropus kroyeri infections in farmed sea bass Dicentrarchus labrax: pathological features. Diseases of Aquatic Organisms, Vol. 57, No. 1-2 (December 2003), pp. (177-180), ISSN 0177-5103.

Merella, P., Garippa, G. \& Salati, F. (2006). Parasites of cage cultured European sea bass Dicentrarchus labrax and gilthead sea bream Sparus aurata from Sardinia (western Mediterranean): first results. Parassitologia, Vol. 48, No. 1-2 (June 2006), pp. 290, ISSN 0048-2951.

Mladineo, I. (2006). Parasites of Adriatic cage reared fish. Acta Adriatica, Vol. 47, No. 1 (June 2006), pp. (23-26), ISSN 1846-0453.

Mladineo, I. \& Marsic-Lucic, J. (2007). Host switch of Lamellodiscus elegans (Monogenea: Monopisthocotylea) and Sparicotyle chrysophrii (Monogenea: Polyopisthocotylea) between Cage-reared Sparids. Veterinary Research Communication, Vol. 31, No. 2 (February 2007), pp. (153-160), ISSN 0165-7380.

Naylor, R.L., Goldburg, R.J., Primavera, J.H., Kautsky, N., Beveridge, M.C.M., Clay, J., Folkes, C., Lubchenco, J., Mooney, H. \& Troells, M. (2000). Effects of aquaculture on world fish supplies. Nature, Vol. 405, No. 6790 (June 2000), pp. (1017-1024), ISSN 0028-0836.

Noga, E.J. (2000). Fish disease. Diagnosis and treatment, Wiley-Blackwell. 367 pp., ISBN 0813806976.

Nowak, B.F. (2007). Parasitic diseases in marine cage culture. An example of experimental evolution of parasites? International Journal for Parasitology, Vol. 37, No. 6 (May 2007), pp. (581-588), ISSN 0020-7519.

Oliver, G. (1982). Microcotyle chrysophrii Van Beneden et Hesse, 1863 (Monogenea, Polyopisthocotylea, Microcotylidae) parasite de Sparus aurata Linneaus, 1758 (Teleostei, Sparidae) dans les étangs littoraux du Languedoc-Roussillon (France). Parasitologie, Vol. 20, pp. (113-118).

Oliver, G. (1987). Les Diplectanidae Bychowsky, 1957 (Monogenea, Monopisthocotylea, Dactylogyridae). Systématique. Biologie. Ontogénie. Écologie. Essai de phylogenèse. Thèse d'État, Mention Sciences, Université des Sciences et Techniques $d u$ Languedoc, Montpellier, France, pp 433.

Ozel, I., Oktener, A. \& Aker, V. (2004). A morphological study (SEM) on a parasitic copepod: Lernenthropus kroyeri (Van Beneden, 1851). Ege University Journal of Fisheries and Aquatic Sciences, Vol. 21, No. 3-4, pp. (335-337), ISSN 1300-1590. 
Paperna, I. \& Baudin Laurencin, F. (1979). Parasitic infections of sea bass, Dicentrarchus labrax, and gilthead sea bream, Sparus aurata, in mariculture facilities in France. Aquaculture, Vol. 16, No. 2 (February 1979), pp. (173-175), ISSN 044-8486.

Poulin, R. \& Rohde, K. (1997). Comparing the richness of metazoan ectoparasite communities of marine fishes: controlling for host phylogeny. Oecologia, Vol. 110, No. 2, pp. (278-283), ISSN 0029-8549.

Reversat, J., Silan, P. \& Maillard, C. (1992). Structure of monogenean populations, ectoparasites of the gilthead sea bream Sparus aurata. Marine Biology, Vol. 112, No. 1 (January 1992), pp. (43-47), ISSN 0025-3162.

Robertsen, G., Olstad, K., Plaisance, L., Bachmann, L. \& Bakke, T.A. (2008). Gyrodactylus salaris (Monogenea, Gyrodactylidae) infections on resident Artic charr (Salvelinus alpinus) in southern Norway. Environmental Biology of Fishes, Vol. 83, No. 1 (September 2008), pp. (99-105), ISSN 0378-1909.

Silan, P. (1984). Biologie compare du développement de Diplectanum aequans et Diplectanum laubieri, monogènes branchiaux de Dicentrarchus labrax. Thèse de doctorat 3ème cycle. Académie de Montpellier. Université des Sciences et Techniques du Languedoc, pp. 275.

Silan, P. \& Maillard, C. (1989). Biologie comparée du développement et discrimination des Diplectanidae ectoparasites du Bar (Teleostei). Annales de Sciences Naturelles, Zoologie, Vol. 10, pp. (31-45).

Sitjà-Bobadilla, A., Conde de Felipe, M. \& Alvarez-Pellitero, P. (2006). In vivo and in vitro treatments against Sparicotyle chrysophrii (Monogenea: Microcotylidae) parasitizing the gills of gilthead sea bream (Sparus aurata L.). Aquaculture, Vol. 261, No. 3 (December 2006) , pp. (856-864), ISSN 044-8486.

Sprent, P. \& Ley, J.P. (1992). Pratique des statistiques non paramétriques, Institut National de la Recherche Agronomique, Paris. 312 pp., ISBN 2-7380-0414-8.

Sterud, E. (2002). Parasites of wild sea bass Dicentrarchus labrax from Norway. Diseases of Aquatic Organisms, Vol. 48, No. 3 (April 2002), pp. (209-212), ISSN 0177-5103.

Timi, J.T. \& Lanfranchi, A.L. (2006). A new species of Cucullanus (Nematoda: Cucullanidae) parasitizing Conger orbignianus (Pisces: Congridae) from Argentinean waters. Journal of Parasitology, Vol. 92, No. 1 (February 2006), pp. (151-154), ISSN 0022-3395.

Toksen, E., Nemli, E. \& Degirmenci, U. (2008). The Morphology of Lernanthropus kroyeri van Beneden, 1851 (Copepoda: Lernanthropidae) Parasitic on Sea Bass, Dicentrarchus labrax (L., 1758), from the Aegean Sea, Turkey. Türkiye Parazitologii Dergisi, Vol. 32, No. 4, pp (386 - 389), ISSN 1300-6320.

Vazzana, M., Cammarata, M., Cooper, E.L. \& Parrinello, N. (2002). Confinement stress in sea bass (Dicentrarchus labrax) depresses peritoneal leukocyte cytotoxicity. Aquaculture, Vol. 210, No 1-4 (July 2002), pp. (231-243), ISSN 044-8486.

Winger, A.C., Kanck, M., Kristoffersen, R. \& Knudsen, R. (2008). Seasonal dynamics and persistence of Gyrodactylus salaris in two riverine anadromous Artic charr populations. Environmental Biology of Fishes, Vol. 83, No. 1 (September 2008), pp. (117-123), ISSN 0378-1909. 


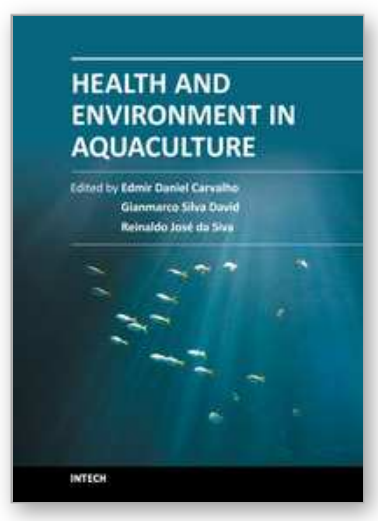

\author{
Health and Environment in Aquaculture \\ Edited by Dr. Edmir Carvalho
}

ISBN 978-953-51-0497-1

Hard cover, 414 pages

Publisher InTech

Published online 11, April, 2012

Published in print edition April, 2012

Aquaculture has been expanding in a fast rate, and further development should rely on the assimilation of scientific knowledge of diverse areas such as molecular and cellular biology, and ecology. Understanding the relation between farmed species and their pathogens and parasites, and this relation to environment is a great challenge. Scientific community is involved in building a model for aquaculture that does not harm ecosystems and provides a reliable source of healthy seafood. This book features contributions from renowned international authors, presenting high quality scientific chapters addressing key issues for effective health management of cultured aquatic animals. Available for open internet access, this book is an effort to reach the broadest diffusion of knowledge useful for both academic and productive sector.

\title{
How to reference
}

In order to correctly reference this scholarly work, feel free to copy and paste the following:

Laetitia Antonelli and Bernard Marchand (2012). Metazoan Parasites of the European Sea Bass Dicentrarchus labrax (Linnaeus 1758) (Pisces: Teleostei) from Corsica, Health and Environment in Aquaculture, Dr. Edmir Carvalho (Ed.), ISBN: 978-953-51-0497-1, InTech, Available from: http://www.intechopen.com/books/healthand-environment-in-aquaculture/metazoan-parasites-of-cultured-european-sea-bass-dicentrarchus-labraxlinneaus-1758-from-corsica-

\section{INTECH}

open science | open minds

\author{
InTech Europe \\ University Campus STeP Ri \\ Slavka Krautzeka 83/A \\ 51000 Rijeka, Croatia \\ Phone: +385 (51) 770447 \\ Fax: +385 (51) 686166 \\ www.intechopen.com
}

\author{
InTech China \\ Unit 405, Office Block, Hotel Equatorial Shanghai \\ No.65, Yan An Road (West), Shanghai, 200040, China \\ 中国上海市延安西路65号上海国际贵都大饭店办公楼 405 单元 \\ Phone: +86-21-62489820 \\ Fax: +86-21-62489821
}


(C) 2012 The Author(s). Licensee IntechOpen. This is an open access article distributed under the terms of the Creative Commons Attribution 3.0 License, which permits unrestricted use, distribution, and reproduction in any medium, provided the original work is properly cited. 